\title{
Kinetics of biodegradation of diesel fuel by enriched microbial consortia from polluted soils
}

\author{
E. Moliterni • R. G. Jiménez-Tusset • \\ M. Villar Rayo $\cdot$ L. Rodriguez • F. J. Fernández • \\ J. Villaseñor
}

Received: 30 June 2011/Revised: 16 October 2011/ Accepted: 13 January 2012/Published online: 22 May 2012

(c) CEERS, IAU 2012

\begin{abstract}
Three microbial consortia were isolated from three polluted soils located at an oil refinery and acclimated to grow on diesel fuel as the sole carbon source. Batch experiments were then conducted with the three consortia to study the kinetics of diesel biodegradation. The effects of temperature $\left(25,30\right.$ and $\left.35^{\circ} \mathrm{C}\right)$ and diesel concentration $(0.5,1$ and $3 \%)$ on the biodegradation of diesel were analysed. Several species were identified in the acclimated microbial consortia, and some of them appeared in more than one consortium. Thermal inhibition was observed at $35{ }^{\circ} \mathrm{C}$. In the rest of experiments, over $80 \%$ of the substrate was degraded after $40 \mathrm{~h}$ of treatment. These results proved the good feasibility of using the polluted sites as sources of mixed consortia for hydrocarbon degradation. However, diesel degradation efficiencies and rates were very similar, suggesting that the acclimation process produced mixed consortia with very similar characteristics; in this context, origin of the soil sample was not a decisive factor. A simple Monod-type kinetic model was used to simulate the biodegradation process, and accurate results were obtained. The $\mu_{\max }$ values were between 0.17 and $0.34 \mathrm{~h}^{-1}$. The results of this study revealed that the consortia can function at high concentrations of hydrocarbons without any sign of growth inhibition, which is important
\end{abstract}

E. Moliterni ( $₫)$ · R. G. Jiménez-Tusset · M. Villar Rayo ·

F. J. Fernández · J. Villaseñor

Chemical Engineering Department,

Institute for Chemical and Environmental Technology

(ITQUIMA), University of Castilla-La Mancha,

13071 Ciudad Real, Spain

e-mail: Elenamoliterni@gmail.com

L. Rodriguez

Alquimia Soluciones Ambientales S.L.,

C/de la Calidad 3, 13250 Daimiel (Ciudad Real), Spain for the design of bioreactors for wastewater treatment with high concentrations of fuel.

Keywords Biological treatment - Growth kinetics . Hydrocarbon · Soil pollution

\section{Introduction}

Currently, petroleum hydrocarbons, a major source of energy, are used to satisfy the demands of everyday life. A direct impact of the use of petroleum products is the widespread contamination of soil and water that occurs during the production, processing and distribution of these substances. Technologies based on physical, chemical or biological principles are commonly used to remediate hydrocarbon-polluted soils (Bhandari et al. 2007). Amongst technologies available, bioremediation, the use of micro-organisms to degrade environmental contaminants, is an attractive approach (Das and Chandran 2011; Juwarkar et al. 2010).

The effects of various factors should be evaluated to determine if biological treatment of a contaminated soil is feasible, and to enhance the effectiveness of bioremediation. Researchers have identified several important factors that affect the efficiencies and rates of biotransformation of hydrocarbons in soils, including the temperature, pollutants concentration, $\mathrm{pH}$, type of microorganism, bioavailability of contaminants, oxygen and nutrients in the medium (Boopathy 2000; Iqbal et al. 2007; Kwapisz et al. 2008; Sabaté et al. 2004; Torres et al. 2005).

It is hypothesised that microbial communities present in old polluted sites or brownfields are typically dominated by bacteria capable of surviving toxic environments and using the pollutant as a substrate for growth (Macnaughton et al. 
1999). Maila et al. (2005) demonstrated that the type and concentration of pollutants, rather than the geographical origin of the soil, may be more important in determining the functional diversity and species diversity of such bacterial communities. Because individual bacterial monocultures can metabolise a limited range of hydrocarbon substrates (Britton 1984), a mixed bacterial consortium with broad enzymatic capacities may be more efficient for remediation, and the advantages of using mixed cultures instead of pure cultures in biodegradation processes, such as higher tolerance to temperature, $\mathrm{pH}$ and salinity, and higher capacity of produce biosurfactants or extracellular surface-active products, have been amply demonstrated (Boopathy 2000).

According to this hypothesis, polluted sites could be the primary source of pollutant-degrading consortia for the biodegradation of hydrocarbons (Margesin and Schinner 2001). Moreover, microorganisms present in these sites could be selected by controlling the adequate environmental factors, such as $\mathrm{pH}$, salinity and organic matter content (Al-Saleh et al. 2009). Vieira et al. (2007) selected different undefined mixed microbial consortia from petroleum pollutes sites, and evaluated their diesel biodegradation efficiencies. Nikakhtari et al. (2009) also used indigenous mixed microbial consortia from polluted sites, whose degradation ability was compared with commercial and donated consortia. However, the real ability, efficiency and rate of these consortia to degrade hydrocarbons should be tested directly in hydrocarbon-water suspensions to avoid the mass transfer limitations that would appear if a soil matrix is present.

In this context, the present work studies the feasibility of using mixed microbial consortia, obtained from different hydrocarbon polluted sites, to degrade diesel fuel under a variety of different experimental conditions. The three microbial consortia used were previously adapted to use diesel through laboratory cultivation, and then biodegradation was studied in water-diesel suspension batch experiments. Moreover, a Monod model was proposed to describe the biodegradation efficiency and kinetics of the different cultures. This research was conducted at the Institute of Chemical and Environmental Technology, University of Castilla-La Mancha (Ciudad Real; Spain) in the spring of 2009.

\section{Materials and methods}

\section{Chemicals}

In this study, conventional petroleum-derived fuel purchased from a petrol station in Ciudad Real, Spain, was employed. The composition of the fuel was estimated according to ASTM standard tests (ASTM 2004), and the analysis revealed that the diesel was composed of $75 \%$ saturated hydrocarbons (primarily paraffins, including $n$-, iso-, and cycloparaffins) and $25 \%$ aromatic hydrocarbons (including naphthalenes and alkylbenzenes). By overlaying a standard diesel pattern (Absolute Standard, Inc. Hamden, CT) and comparing the retention times of the chromatographic profile of the diesel, the chain length of $n$-alkanes was determined to be between 10 and 26 carbon atoms. Other compounds such as pristane and phytane were also identified. The density (832 g/L) was measured according to the method proposed by the International Organisation for Standardisation (ISO-3675 1998).

Bushnell-Haas (BH) broth, which contains $0.2 \mathrm{~g} / \mathrm{L}$ $\mathrm{MgSO}_{4}, 0.02 \mathrm{~g} / \mathrm{L} \mathrm{CaCl}_{2}, 1 \mathrm{~g} / \mathrm{L} \mathrm{KH}_{2} \mathrm{PO}_{4}, 1 \mathrm{~g} / \mathrm{L}\left(\mathrm{NH}_{4}\right)_{2}$ $\mathrm{HPO}_{4}, 0.05 \mathrm{~g} / \mathrm{L} \mathrm{FeCl}_{3}$ and $1 \mathrm{~g} / \mathrm{L} \mathrm{KNO}_{3}$, was used in the consortia acclimation process. The media was adjusted to pH $7 \pm 0.2$ and was autoclaved to prevent contamination.

$n$-Hexane was used to prepare samples for gas chromatography (Merck-Darmstadt, Germany). All chemicals used for the preparation of microbial media (BH broth and Luria-Bertani broth) were reagent-grade and were purchased from Difco Laboratories.

\section{Isolation and identification of diesel-degrading} consortia

Three soil samples contaminated with hydrocarbons were collected from an oil refinery near Ciudad Real, Spain. The soil samples were named as SA, SB and SC. Table 1 shows their concentrations of total petroleum hydrocarbons (TPH), total heterotrophic bacteria (THB) and diesel degrading bacteria (DDB).

To obtain three different consortia (named as XA, XB and XC, obtained from soils SA, SB and SC, respectively), the soil samples were sieved through a $2-\mathrm{mm}$ screen, and the microorganisms were immediately isolated. Briefly, $5 \mathrm{~g}$ of each soil sample was transferred to flasks containing $50 \mathrm{~mL}$ of Bushnell-Haas broth. The flasks were agitated in an Ecotron incubator shaker $(50 \mathrm{rpm})$ for $12 \mathrm{~h}$ at $26{ }^{\circ} \mathrm{C}$. Upon completion, the water/soil suspension was centrifuged at 1,500 rpm for $15 \mathrm{~min}$, and the supernatants were inoculated in $1 \%(\mathrm{v} / \mathrm{v})$ diesel as the sole carbon source. Prior to the addition of the micro-organisms, the diesel was sterilised by filtration (Millex, pore size of $0.2 \mu \mathrm{m}$; Millipore). The consortia were enriched via weekly aerobic cultivations in the Ecotron incubator shaker at $50 \mathrm{rpm}$ and $26{ }^{\circ} \mathrm{C}$ for 3 months, using diesel as the sole carbon source. Using this procedure, three adapted microbial consortia were obtained.

To achieve a microbiological characterisation, serial dilutions (1/10) of the adapted consortia were grown in Luria-Bertani agar plates with $25 \mathrm{~g} / \mathrm{L}$ of glucose at $26{ }^{\circ} \mathrm{C}$. 
Table 1 Initial concentration of TPH and microorganisms in soils

\begin{tabular}{llll}
\hline Parameter & SA & SB & SC \\
\hline TPH (mg/Kg) & 16.6 & 770.4 & 25 \\
THB (NMP/g) & $1.3 \times 10^{6}$ & $2.3 \times 10^{8}$ & $28 \times 10^{8}$ \\
DDB (NMP/g) & $0.4 \times 10^{6}$ & $2.3 \times 10^{8}$ & $24 \times 10^{6}$
\end{tabular}

$T P H$ total petroleum hydrocarbon, $T H B$ total heterotrophic bacteria, $D D B$ diesel-degrading bacteria

After 4 days, the colonies were streaked onto a new agar plate to isolate each strain. To characterise the isolates, their oxidase reactions, catalase reactions and morphology were determined (colony aspect, size, shape and colour), and a Gram stain test was conducted. Bacteria were tested and identified with physiological test kits, according to Analytical Profile Index micromethods API 20 NE, API 20E and API Staph (BioMérieux, Lyon, France). To preserve the strains, the bacterial isolates were stored in $35 \%$ glycerol in liquid nitrogen.

\section{Experimental system}

Batch experiments were conducted to study the efficiencies and kinetics of diesel biodegradation using the three selected consortia. For each consortium, the effects of temperature and diesel concentration were studied, as shown in Table 2.

A total of 26 batch biodegradation experiments were carried out in 1-L reactors. Each reactor contained $500 \mathrm{~mL}$ of $\mathrm{BH}$ broth and an initial diesel concentration of $0.5,1$ and $3 \%(\mathrm{v} / \mathrm{v})$. The reactors were sealed to avoid potential losses of diesel and were placed inside an orbital shaker bath with a temperature controller. The reactors were

Table 2 Experiments done for the diesel biodegradation

\begin{tabular}{lllll}
\hline$C_{0}(\% \mathrm{v} / \mathrm{v})$ & Consortium & \multicolumn{2}{c}{$T\left({ }^{\circ} \mathrm{C}\right)$} & \\
\cline { 3 - 5 } & & 25 & 30 & 35 \\
\hline 0.5 & Abiotic & - & $\times$ & - \\
& XA & $\times$ & $\times$ & - \\
& XB & $\times$ & $\times$ & - \\
& XC & $\times$ & $\times$ & - \\
1 & Abiotic & $\times$ & $\times$ & $\times$ \\
& XA & $\times$ & $\times$ & $\times$ \\
& XB & $\times$ & $\times$ & $\times$ \\
& XC & $\times$ & $\times$ & $\times$ \\
3 & Abiotic & - & $\times$ & - \\
& XA & $\times$ & $\times$ & - \\
& XB & $\times$ & $\times$ & - \\
& XC & $\times$ & $\times$ & - \\
\hline
\end{tabular}

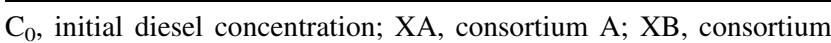
$\mathrm{B}$; XC, consortium $\mathrm{C}$; -, Not tested; $\times$, tested agitated at $130 \mathrm{rpm}$ to ensure substrate availability and oxygen transfer. The dissolved oxygen concentration was previously measured under the aforementioned operating conditions with an YSI 5000 oxygen probe to ensure aerobic conditions (oxygen concentrations between 6 and $7 \mathrm{mg} / \mathrm{L}$ approximately). Finally, each reactor was inoculated with one of the acclimated consortia, as indicated in Table 2. The reactors were maintained at 25,30 or $35^{\circ} \mathrm{C}$ for 8 days to study the effects of temperature. Aliquots were sampled to monitor the biodegradation of diesel and biomass growth. Three non-inoculated control reactors (that is, with no consortium addition) were incubated at 25 , 30 or $35^{\circ} \mathrm{C}$ with $500 \mathrm{~mL}$ of BH broth and $0.5,1$ and $3 \%$ (v/v) diesel to account for abiotic losses.

Analytical methods

The THB and DDB were enumerated in soils by the most probable number (MPN) method (Youssef et al. 2010).

Biomass growth and the residual diesel concentration were determined from 10-ml samples which were collected by duplicate during the biodegradation experiments. Biomass concentration was determined by direct optical density (OD) measurements at $600 \mathrm{~nm}$, as described by Sadouk et al. (2008). A Shimadzu UV-1700 spectrophotometer was used to determine the OD of the cultures, and each measurement was performed in triplicate. A correlation curve (Eq. 1) relating the $\mathrm{OD}_{600}$ to the dry weight (DW) concentration was developed to calculate the biomass concentration $(\mathrm{mg} / \mathrm{L})$ :

$\mathrm{DW}(\mathrm{g} / \mathrm{L})=0.214 \mathrm{OD}+0.0042 ; \quad\left(r^{2}=0.9756\right)$

The average residual concentration of diesel was determined by TPH measurements. The hydrocarbon fraction was extracted into $2 \mathrm{~mL}$ of $n$-hexane in a one-step extraction procedure. The TPH concentrations were analysed via gas chromatography using a Thermo-Fischer Trace GC Ultra gas chromatograph equipped with a flame ionisation detector, according to ISO method (ISO 9377-2 2000). The hydrocarbons were separated on a micro ultra fast capillary column $(5 \mathrm{~m} \times 0.1 \mathrm{~mm}$ i.d. $\times 0.4 \mu \mathrm{m})$, and the injector and detector were maintained at a constant temperature of 250 and $280{ }^{\circ} \mathrm{C}$, respectively. During the chromatographic run, the column was maintained at $62{ }^{\circ} \mathrm{C}$ for $0.1 \mathrm{~min}$, and the temperature of the column was increased at a rate of $180{ }^{\circ} \mathrm{C} / \mathrm{min}$ until a final temperature of $280{ }^{\circ} \mathrm{C}$ was attained. The final temperature was maintained for $2.7 \mathrm{~min}$, and helium was applied as the carrier gas. The injection volume was set to $1 \mu \mathrm{L}$, and a split injection mode was employed. Qualitative analysis was performed using a standard mixture of $n$-alkanes (Absolute Standard, Inc. Hamden, CT), and the calibration curves were obtained from dilutions of the reference solution. 


\section{Biodegradation kinetics}

To analyse the kinetics of biodegradation, the concentrations of micro-organisms $(X)$ and residual diesel $(S)$ were determined as a function of time, and the following equations were applied to fit the experimental data:

$$
\begin{aligned}
& \frac{\mathrm{d} X}{\mathrm{~d} t}=\frac{\mu_{\max }\left(S-I_{0}\right)}{K_{\mathrm{s}}+\left(S-I_{0}\right)} X \\
& \left(\frac{-\mathrm{d} S}{\mathrm{~d} t}\right)=\frac{\mu_{\max }\left(S-I_{0}\right)}{K_{\mathrm{s}}+\left(S-I_{0}\right)} X \frac{1}{Y_{\mathrm{x} / \mathrm{s}}}
\end{aligned}
$$

where $S$ is the substrate or diesel concentration (g TPH/L), $X$ is the concentration of microorganisms $(\mathrm{g} / \mathrm{L}), t$ is the residence time $(\mathrm{h}), \mu_{\max }$ is the maximum specific growth rate $\left(\mathrm{h}^{-1}\right), Y_{\mathrm{x} / \mathrm{s}}$ is the biomass yield $(\mathrm{g} / \mathrm{g}), K_{\mathrm{s}}$ is the halfsaturation coefficient ( $\mathrm{g}$ TPH/L) and $I_{0}$ is the inert residual substrate concentration (g TPH/L).

Equations 2 and 3 were solved simultaneously using the Gauss-Newton algorithm. An initial set of values $\left(\mu_{\max }, K_{\mathrm{s}}\right.$ and $Y_{\mathrm{x} / \mathrm{s}}$ ) were assigned to the parameters, and after several iterations, the values of the parameters that yielded the lowest sum of squared error (SSE) were selected. The SSE of the parameters was determined according to the following equation:

$\chi=\sum_{i=1}^{n}\left(\left(X_{i}-X_{\text {meas }, i}\right)_{i}^{2}+\left(S_{i}-S_{\text {meas }, i}\right)_{i}^{2}\right)$

where $n$ is the number of data points, $X_{i}$ and $S_{i}$ are the calculated values of the variable at the $i$ th measurement and $X_{\text {meas }, i}$ and $S_{\text {meas, } i}$ are the actual values at the $i$ th measurement.

\section{Results and discussion}

\section{Composition of the bacterial community}

Cultures enriched in suspensions of diesel, grew rapidly and became turbid after $24 \mathrm{~h}$ of incubation. After 3 months of successive transfers, only eight pure bacterial strains were isolated from each consortium (see Table 3) and they were identified according to the Analytical Profile Index method, previously indicated. Some species, as Staphylococcus lentus, Stenotrophomonas maltophilia and

\begin{tabular}{|c|c|c|c|c|c|c|c|c|c|c|c|}
\hline $\begin{array}{l}\text { Isolate } \\
\text { type }\end{array}$ & Colour & Convex & Opaque & Margin & $\begin{array}{l}\text { Cell } \\
\text { morphology }\end{array}$ & $\begin{array}{l}\text { Gram } \\
\text { coloration }\end{array}$ & Oxidase & Catalase & $\begin{array}{l}\text { Identification } \\
\text { API }\end{array}$ & Genus & Species \\
\hline XA1 & Yellow & + & - & I & $\mathrm{R}$ & - & $\mathrm{w}$ & $\mathrm{w}$ & $20 \mathrm{NE}$ & NI & \\
\hline XA2 & Greyish & - & + & $\mathrm{E}$ & $\mathrm{R}$ & - & + & + & $20 \mathrm{NE}$ & Rhizobium & radiobacter \\
\hline XA3 & White & \pm & - & $\mathrm{E}$ & $\mathrm{R}$ & - & + & + & $20 \mathrm{NE}$ & Aeromonas & sobria \\
\hline XA4 & Orange & \pm & \pm & $\mathrm{E}$ & $\mathrm{C}$ & + & - & + & Staph & Staphylococcus & lentus \\
\hline XA5 & Cream & + & + & I & $\mathrm{R}$ & + & - & + & $20 \mathrm{NE}$ & NI & \\
\hline XA6 & White & + & - & I & $\mathrm{C}$ & - & - & - & $20 \mathrm{NE}$ & NI & \\
\hline XA7 & Cream & + & + & I & $\mathrm{R}$ & - & + & + & $20 \mathrm{NE}$ & Ochrobactrum & anthropi \\
\hline XA9 & White & - & + & $\mathrm{E}$ & $\mathrm{R}$ & - & + & + & $20 \mathrm{NE}$ & Achromobacter & xylosoxidans \\
\hline XB1 & Yellow & - & - & $\mathrm{E}$ & $\mathrm{R}$ & - & $\mathrm{w}$ & + & $20 \mathrm{NE}$ & Burkholderia & cepacia \\
\hline XB2 & White & + & \pm & $\mathrm{E}$ & $\mathrm{R}$ & - & + & + & $20 \mathrm{NE}$ & Pseudomonas & fluorescens \\
\hline XB4 & Yellow & + & - & $\mathrm{E}$ & $\mathrm{R}$ & - & - & + & $20 \mathrm{E}$ & Stenotrophomonas & maltophilia \\
\hline XB5 & Cream & + & + & $\mathrm{E}$ & $\mathrm{R}$ & - & + & + & $20 \mathrm{NE}$ & Achromobacter & denitrificans \\
\hline XB6 & Orange & \pm & \pm & $\mathrm{E}$ & $\mathrm{C}$ & + & - & + & Staph & Staphylococcus & lentus \\
\hline XB7 & Cream & + & + & I & $\mathrm{R}$ & - & + & + & $20 \mathrm{NE}$ & Ochrobactrum & anthropi \\
\hline XB8 & White & + & + & $\mathrm{E}$ & $\mathrm{R}$ & - & + & $\mathrm{w}$ & $20 \mathrm{NE}$ & Sphingomonas & paucimobilis \\
\hline XB9 & White & - & + & $\mathrm{E}$ & $\mathrm{C}$ & - & - & + & $20 \mathrm{NE}$ & NI & \\
\hline $\mathrm{XC1}$ & Yellow & + & - & $\mathrm{E}$ & $\mathrm{R}$ & - & - & + & $20 \mathrm{E}$ & Stenotrophomonas & maltophilia \\
\hline $\mathrm{XC} 2$ & Cream & + & - & $\mathrm{E}$ & $\mathrm{R}$ & - & + & $\mathrm{w}$ & $20 \mathrm{NE}$ & Sphingobacterium & multivorum \\
\hline $\mathrm{XC} 3$ & Yellowish & - & - & $\mathrm{E}$ & $\mathrm{R}$ & - & + & $\mathrm{w}$ & $20 \mathrm{NE}$ & Sphingobacterium & spp. \\
\hline $\mathrm{XC} 4$ & Yellow & - & - & $\mathrm{E}$ & $\mathrm{C}$ & + & - & $\mathrm{w}$ & Staph & Staphylococcus & sciuri \\
\hline XC5 & Orange & \pm & \pm & $\mathrm{E}$ & $\mathrm{C}$ & + & - & + & Staph & Staphylococcus & lentus \\
\hline XC6 & White & - & + & $\mathrm{E}$ & $\mathrm{C}$ & - & - & + & $20 \mathrm{NE}$ & $\mathrm{NI}$ & \\
\hline $\mathrm{XC7}$ & White & - & + & I & $\mathrm{C}$ & + & - & + & Staph & Micrococcus & spp. \\
\hline $\mathrm{XC} 8$ & White & + & + & $\mathrm{E}$ & $\mathrm{R}$ & - & + & + & $20 \mathrm{NE}$ & Pseudomonas & fluorescens \\
\hline
\end{tabular}

Table 3 Biochemical and growth characteristics of isolated bacterial cultures

+ , positive; -, negative; \pm , variable; w, weak; NI, not identified; E, entire; I, irregular; R, rod; C, coccus 
Pseudomonas fluorescens, appeared in more than one consortium. The isolation of these species is not surprising due to their frequency in contaminated soils (Barathi and Vasudevan 2001; Ueno et al. 2007). All of the other species found in the consortia have been shown to degrade hydrocarbons (Chaineau et al. 1999; Lafortune et al. 2009; Medina-Moreno et al. 2005; Nikakhtari et al. 2009; Owsianiak et al. 2009; Rahman et al. 2002).

\section{Diesel biodegradation by isolated consortia}

Figure 1 illustrates the results of diesel biodegradation and biomass growth in the batch experiments. The data shown correspond to the biodegradation of $1 \%(\mathrm{v} / \mathrm{v})$ diesel at 25 , 30 and $35{ }^{\circ} \mathrm{C}$ for consortia XA, XB and XC (data for the degradation of 0.5 and $3 \%$ (v/v) diesel are not presented). The curves represent the general trend of each consortium; thus, the entire data set is not shown. The results revealed that the behaviour of the three consortia was similar. Moreover, for all of the consortia, a direct relationship between microbial growth and substrate depletion was observed. The maximum amount of substrate utilised by the microbes was observed during the exponential growth phase, and the concentration of biomass increased with an increase in the initial concentration of substrate during the lag phase.

In the present study, inhibition was clearly observed at $35^{\circ} \mathrm{C}$, and less than $35 \%$ diesel biodegradation occurred in all of the consortia at this temperature. As shown in Fig. 1, except for assays conducted at $35^{\circ} \mathrm{C}$, over $80 \%$ of the substrate was degraded after $40 \mathrm{~h}$ of treatment, and a maximum removal efficiency of $98 \%$ was obtained. A further reduction in the diesel concentration was not observed after $80 \mathrm{~h}$ of treatment. Similarly, Márquez-Rocha et al. (2001) attained nearly $90 \%$ diesel consumption after 13 days of bioremediation. In general, the diesel biodegradation by the consortia was faster than that of other microbes reported in the literature (Vieira et al. 2007; Young et al. 2005). These results prove the good feasibility of using polluted sites as source of mixed consortia for hydrocarbon degradation, as also has been found in similar previous works (Nikakhtari et al. 2009; Vieira et al. 2007). However, in the present work no important differences were observed between the three consortia, suggesting that the acclimation process produced mixed consortia with very similar characteristics and efficiencies, and the origin of the soil sample was not a decisive factor.

In all of the bioremediation experiments, a layer of creamy foam was produced on the surface of the medium, and the foam was not observed in abiotic experiments. Previous studies suggest that some species in the consortia (P. fluorescens, Ochrobactrum antrhopii and Corynebacterium) are capable of generating extracellular surface- active products that improve the consumption and transport of oily substrates by increasing the solubility of oil (Banat 1995; Ron and Rosenberg 2001). Thus, the aforementioned consortia may have produced surface-active materials to improve the use of diesel.

Although the experiments were carried out in closed systems, the substrate may have volatilised during the sampling process. To identify substrate losses by volatilisation, the concentration of TPH in the abiotic assays was measured, and abiotic losses of diesel were estimated to be 5.7, 8.67 and $11.33 \%$ at 25,30 and $35{ }^{\circ} \mathrm{C}$, respectively.

\section{Parameter estimation}

To evaluate the biodegradation kinetics, the experimental data from the batch experiments were fitted to Eqs. 2 and 3. As an example, Fig. 2 shows the experimental data for consortium XA at $25^{\circ} \mathrm{C}$ and an initial diesel concentration of $0.5 \%(\mathrm{v} / \mathrm{v})$, as well as the simulated curves of the Monod model. In most of the experiments, the results of the model agreed with the experimental data, indicating that the kinetic model could predict the diesel biodegradation over time. Numerous mathematical models based on the Monod equation have been proposed in the literature to explain the biodegradation of hydrocarbons. In some cases, additional parameters were used to describe the system. For instance, Ghoshal and Luthy (1998) and Mukherji and Weber (1998) considered the mass transfer of naphthalene from the organic phase to the aqueous phase. The aforementioned model was based on the premise that microorganisms can only metabolise TPH when it is in the dissolved state; thus, these models can be used to determine if biodegradation is controlled by the rate of dissolution or by the intrinsic rate of biodegradation by the microorganisms. Despite the fact that the model proposed in this study did not consider mass transfer, the model satisfied the initial purpose of the investigation, that is, the proposed model provided a simple representation of the biodegradation rate and efficiency.

Table 4 shows the kinetics parameters obtained from the mathematical fitting. Similar trends were again observed between the three consortia used. The highest $\mu_{\max }$ value $\left(0.34 \mathrm{~h}^{-1}\right)$ was obtained by consortium XB at $30{ }^{\circ} \mathrm{C}$ and an initial diesel concentration of $0.5 \%(\mathrm{v} / \mathrm{v})$, suggesting, in principle, that consortia isolated from a highly contaminated soil (SB) may provide a higher biodegradation rate of diesel. However, this hypothesis cannot be verified, because, all of the consortia displayed similar values. Except for the assays conducted at $35^{\circ} \mathrm{C}, \mu_{\max }$ ranged between 0.17 and $0.34 \mathrm{~h}^{-1}$, which is slightly higher than those obtained in previous studies (Whang et al. 2008; Young et al. 2005). 
(a1) XA

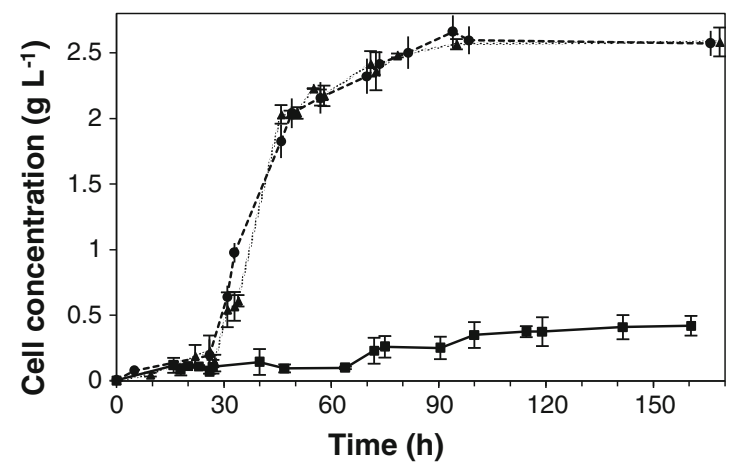

(b1) XB

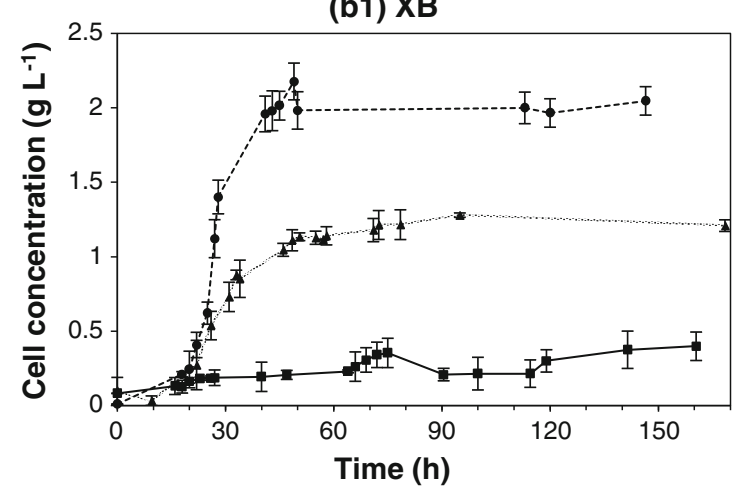

(c1) XC

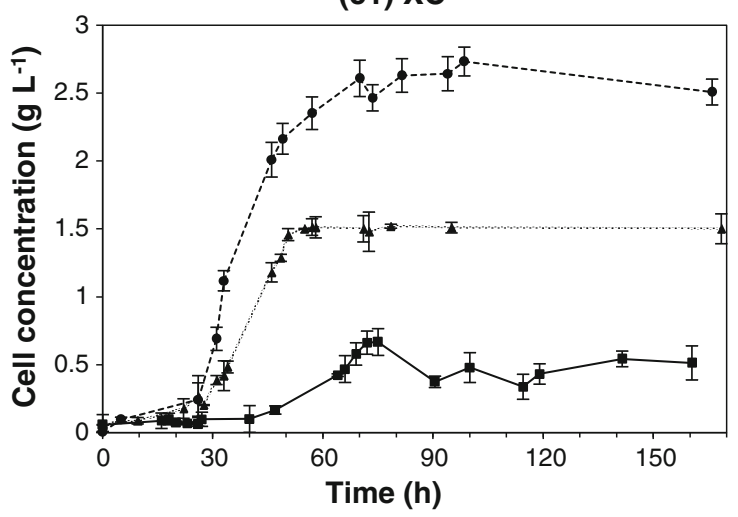

Fig. $1 \mathrm{TPH}$ and biomass concentrations over time for consortia XA (a), $\mathrm{XB}(\mathbf{b})$ and $\mathrm{XC}(\mathbf{c})$ at 25,30 and $35{ }^{\circ} \mathrm{C}$ with $1 \%(\mathrm{v} / \mathrm{v})$ of initial diesel concentration. Symbols (filled triangles, filled circles, filled squares) represent the concentration of biomass at 25,30 and $35{ }^{\circ} \mathrm{C}$, respectively. Symbols (open triangles, open circles, open squares)

The half-saturation constant was highly correlated with the maximum utilisation rate (Schirmer et al. 2000); thus at various initial diesel concentrations, the value of $K_{\mathrm{s}}$ increased from 3 to $5 \mathrm{~g}$ of TPH/L as $\mu_{\max }$ increased $\left(K_{\mathrm{s}}\right.$ is not included in Table 4). Similar $K_{\mathrm{s}}$ values were reported by Young et al. (2005), who reported a $K_{\mathrm{s}}$ value of $3.196 \mathrm{~g}$ of TPH/L.

Table 4 also displays the correlation coefficients of the model and the significance of the correlations. As shown in the table, the biodegradation model acceptably fitted the experimental data ( $r^{2}$ between 0.8545 and 0.9974$)$. The proposed (a2) XA

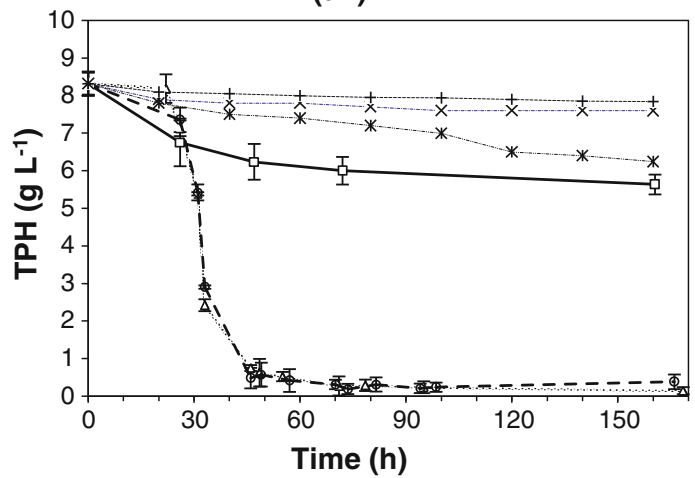

(b2) XB

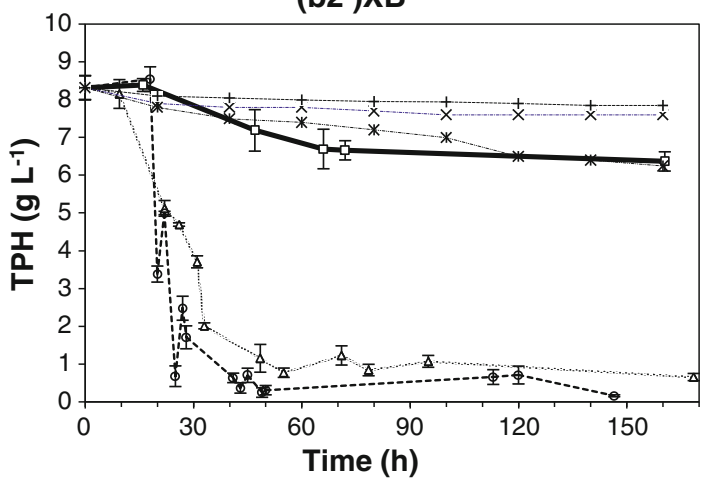

(c2) XC

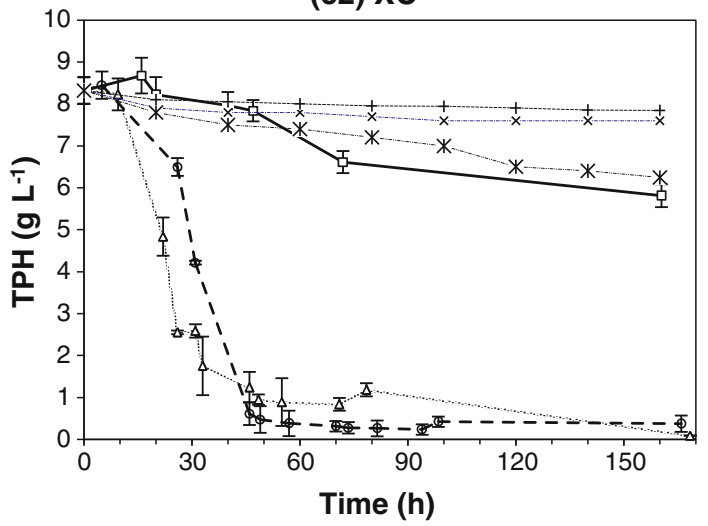

represent the concentration of TPH at 25,30 and $35{ }^{\circ} \mathrm{C}$, respectively. Symbols (pluses, times, asterisks) represent the concentration of TPH in abiotic experiments at 25,30 and $35^{\circ} \mathrm{C}$, respectively. Data are the mean of two samples. Lines indicate trends only

model did not consider temperature inhibition or other inhibitory effects, and the values of $r^{2}$ for $\mathrm{XA}, \mathrm{XB}$ and $\mathrm{XC}$ fittings at $35^{\circ} \mathrm{C}$ were $0.4569,0.56$ and 0.6671 , respectively. The correlation coefficients were significant, and the variables were positively related at the $p<0.05$ level.

Effect of initial diesel concentration

At the lowest initial diesel concentration, residual diesel $\left(I_{0}\right)$ was not detected in the medium; however, as the initial 


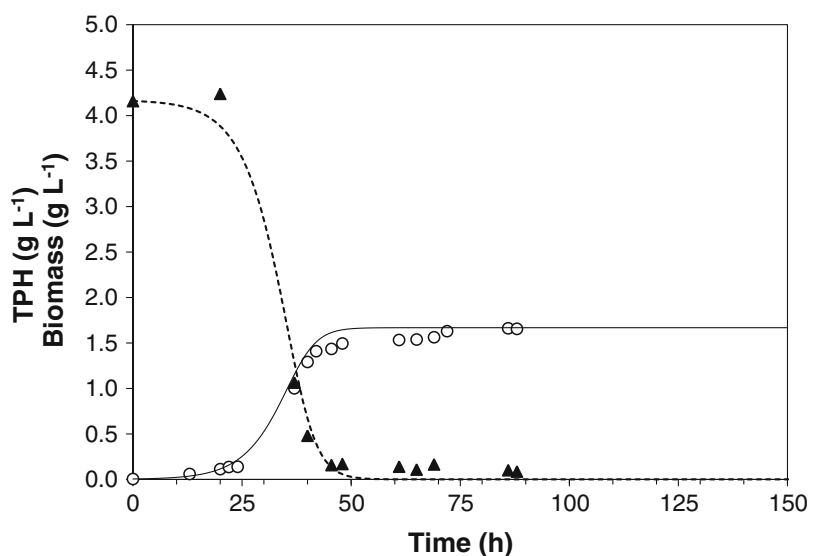

Fig. 2 Simulation of batch experiments [consortium XA at $25{ }^{\circ} \mathrm{C}$ and an initial diesel concentration of $0.5 \%(\mathrm{v} / \mathrm{v})]$. Symbols (filled triangles, open circles) represent the experimental concentration of TPH and biomass, respectively, and the lines indicate the theoretical results

diesel concentration increased, higher concentrations of residual diesel were observed (Table 4).

The $\mu_{\max }$ and $Y_{\mathrm{x} / \mathrm{s}}$ parameters, dependent on initial diesel concentration, offered similar trends in all consortia. Figure 3 shows the evolution of $\mu_{\max }$ as a function of the initial diesel concentration. It decreased from the maximum value (when using $0.5 \%$ diesel) to approximately constant values (when using 1 and $3 \%$ diesel).

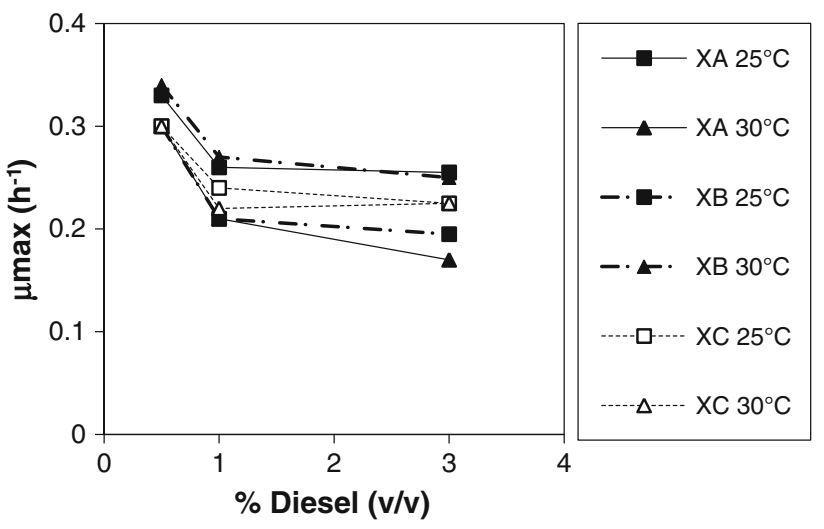

Fig. 3 The dependence of the maximum specific growth rate of consortia XA, XB and XC on the initial diesel concentration. Dots represent experimental data, and lines represent general trends

Regarding $Y_{\mathrm{x} / \mathrm{s}}$, it decreased with an increase in the initial diesel concentration in all cases (Fig. 4). In the previous biodegradation studies on other contaminants, a similar trend in biomass yield was observed (Lee et al. 1993; Paslawski et al. 2009). Lee et al. (1993) demonstrated that the substrate can penetrate into the cell membrane and interact with microbial membrane proteins, causing the proteins to malfunction and reducing the biomass yield. The variability in biomass yield could also be attributed to uncoupled growth. Senez (1962) introduced the term uncoupled growth to describe the effects of
Table 4 The estimated parameters $\left(\mu_{\max }\right.$ and $\left.Y_{\mathrm{x} / \mathrm{s}}\right)$ of the Monod equation and the error associated with the batch experiments $d f$ degrees of freedom, $t$ Student's $t$ test

\begin{tabular}{|c|c|c|c|c|c|c|c|c|}
\hline Consortium & $T\left({ }^{\circ} \mathrm{C}\right)$ & $\begin{array}{l}C_{0} \\
(\% \mathrm{v} / \mathrm{v})\end{array}$ & $\begin{array}{l}I_{0} \\
(\mathrm{~g} \text { TPH/L) }\end{array}$ & $\mu_{\max }\left(\mathrm{h}^{-1}\right)$ & Overall $Y_{\mathrm{x} / \mathrm{s}}$ & $r^{2}$ & $d f$ & $t$ \\
\hline \multirow[t]{7}{*}{ XA } & \multirow[t]{3}{*}{25} & 0.5 & 0 & 0.33 & 0.40 & 0.9789 & 15 & 18.554 \\
\hline & & 1 & 0 & 0.26 & 0.25 & 0.9599 & 17 & 14.118 \\
\hline & & 3 & 0.7 & 0.26 & 0.16 & 0.9476 & 13 & 10.695 \\
\hline & \multirow[t]{3}{*}{30} & 0.5 & 0 & 0.30 & 0.40 & 0.9694 & 12 & 13.679 \\
\hline & & 1 & 0.2 & 0.21 & 0.27 & 0.9560 & 12 & 11.289 \\
\hline & & 3 & 1 & 0.17 & 0.15 & 0.9583 & 13 & 12.091 \\
\hline & 35 & 1 & 6 & 0.06 & 0.08 & 0.4569 & 16 & 2.0550 \\
\hline \multirow[t]{7}{*}{$\mathrm{XB}$} & \multirow[t]{3}{*}{25} & 0.5 & 0 & 0.30 & 0.50 & 0.9974 & 15 & 53.604 \\
\hline & & 1 & 1 & 0.21 & 0.08 & 0.9652 & 16 & 14.763 \\
\hline & & 3 & 4 & 0.20 & 0.15 & 0.8846 & 12 & 6.571 \\
\hline & \multirow[t]{3}{*}{30} & 0.5 & 0 & 0.34 & 0.41 & 0.9791 & 14 & 18.013 \\
\hline & & 1 & 0.2 & 0.27 & 0.15 & 0.9870 & 13 & 22.142 \\
\hline & & 3 & 5 & 0.25 & 0.15 & 0.8710 & 9 & 5.319 \\
\hline & 35 & 1 & 6.4 & 0.10 & 0.19 & 0.5600 & 18 & 2.868 \\
\hline \multirow[t]{7}{*}{$\mathrm{XC}$} & \multirow[t]{3}{*}{25} & 0.5 & 0 & 0.30 & 0.28 & 0.9528 & 15 & 12.155 \\
\hline & & 1 & 1 & 0.24 & 0.22 & 0.9531 & 17 & 12.984 \\
\hline & & 3 & 1 & 0.23 & 0.19 & 0.9551 & 12 & 11.167 \\
\hline & \multirow[t]{3}{*}{30} & 0.5 & 0 & 0.30 & 0.45 & 0.8545 & 14 & 6.155 \\
\hline & & 1 & 0.05 & 0.22 & 0.30 & 0.9491 & 12 & 10.438 \\
\hline & & 3 & 0.5 & 0.23 & 0.16 & 0.9424 & 9 & 8.452 \\
\hline & 35 & 1 & 6 & 0.18 & 0.38 & 0.6671 & 18 & 3.799 \\
\hline
\end{tabular}


limited assimilation capacities on growth yield. The source of the variability in biomass yield in the present work is not clear, and it is supposed that the presence of high diesel concentrations caused a higher biomass growth, but a significant increase in substrate requirements for biomass maintenance. As the temperature increased from 25 to $30{ }^{\circ} \mathrm{C}$, the order of magnitude of the biomass yield remained relatively constant, indicating that biomass yield

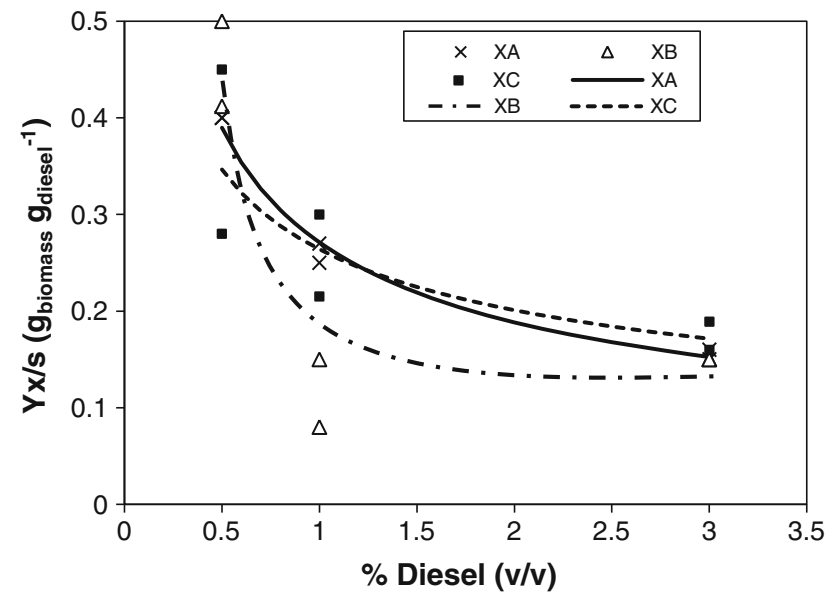

Fig. 4 Effect of the initial diesel concentration on the biomass yield. Lines indicate general trends of media values between 25 and $30{ }^{\circ} \mathrm{C}$ was significantly affected by uncoupled growth and only slightly affected by temperature.

To discuss the causes of yield variability, an additional equation can be introduced:

$\mu_{\max }=Y_{\mathrm{x} / \mathrm{s}} \times q_{\mathrm{s}, \max }$

where $q_{\mathrm{s}, \max }(\mathrm{g}$ diesel $\mathrm{g} / \mathrm{biomass} / \mathrm{h}$ ) is the specific rate of substrate consumption. Equation 5 indicates that the growth rate depends on the rate of substrate consumption $\left(q_{\mathrm{s}, \max }\right)$ and the efficiency of the transformation of substrate to biomass $\left(Y_{\mathrm{x} / \mathrm{s}}\right)$ (van Uden 1969). Taking Eq. 5 into account, to determine if growth inhibition was caused by a decrease in the biomass yield or a decrease in the rate of substrate consumption, all the biomass yield values were plotted against the corresponding $\mu_{\max }$ values, and a linear relationship was obtained for all consortia and temperatures (Fig. 5), indicating that $q_{\mathrm{s}, \max }$ remained constant. Thus, as expected, $q_{\mathrm{s}, \max }$ did not change as the initial diesel concentration increased, and the observed decrease in the growth rate could be explained by a reduction in biomass yield. The results of this study revealed that the consortia can function at high concentrations of hydrocarbons without any sign of growth inhibition, which is important for the design of bioreactors for wastewater treatment with high concentrations of fuel. In addition, the results suggested that uncoupled growth must be considered in the biodegradation process.
Fig. 5 The relationship between the maximum specific growth rate and the biomass yield coefficient at $25^{\circ} \mathrm{C}$ (filled squares) and $30^{\circ} \mathrm{C}$ (filled triangles) for consortium $\mathrm{XA}$ (a), XB (b) and XC (c). Dots represent experimental data, and lines indicate general trends (a)
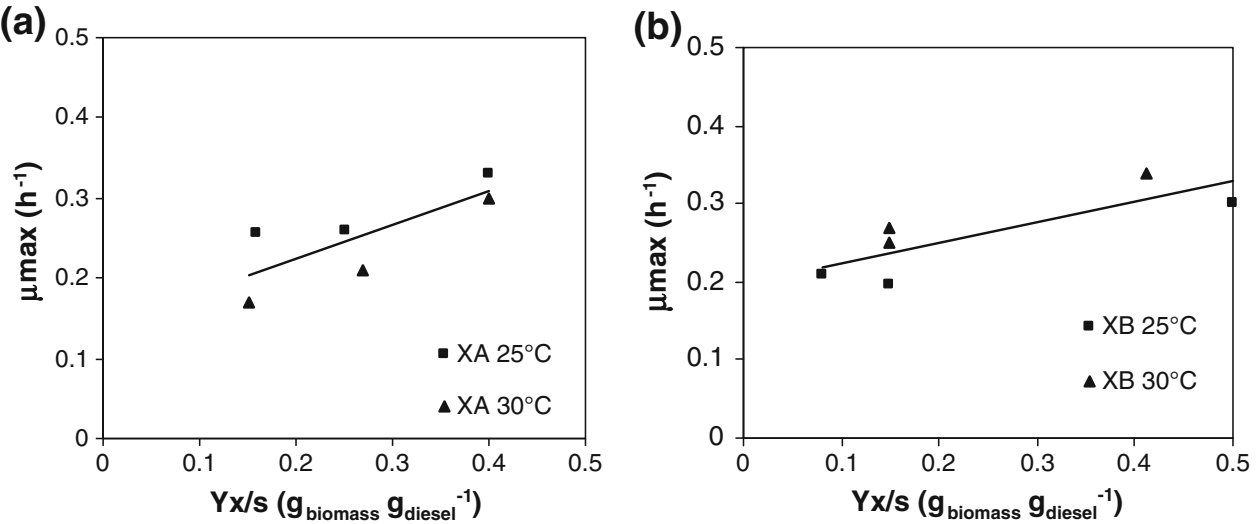

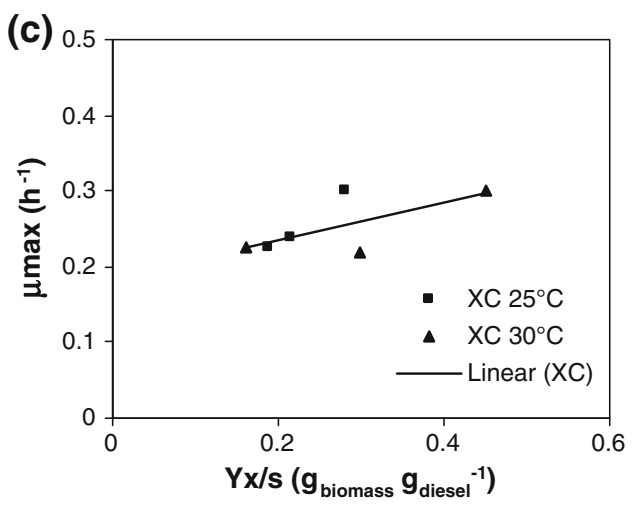


The correlation coefficients shown in Table 4 revealed that the fit of the model to the experimental data diminished as the initial diesel concentration increased, indicating that the proposed model did not consider uncoupled growth.

\section{Effect of temperature}

Temperature is one of the most important factors affecting the efficiency of biodegradation (Iqbal et al. 2007). In the present study, the final efficiency of biodegradation remained constant at temperatures between 25 and $30^{\circ} \mathrm{C}$, and satisfactory growth rates were observed. However, at $35^{\circ} \mathrm{C}$, little microbial growth was observed, and less than $35 \%$ degradation was obtained; hence, the biological reaction was clearly inhibited. Under these conditions, yellowish biomass aggregates adhered to the walls of the reactor was observed, indicating biomass disintegration and lysis. Moreover, large amounts of foam were also observed at $35^{\circ} \mathrm{C}$, especially on the second day of the experiment. Consequently, $\mu_{\max }$ decreased by more than 76, 63 and $25 \%$ for consortium XA, XB and XC, respectively. Thermal inhibition may have occurred, because, consortia isolated from the soils were rarely subjected to high temperatures for extended periods of time.

\section{Conclusion}

Only a small number of species were identified in the acclimated microbial consortia, and some of them appeared in more than one consortium, as well as those obtained in similar previous investigations. Except for assays conducted at $35{ }^{\circ} \mathrm{C}$, over $80 \%$ of the substrate was degraded after $40 \mathrm{~h}$ of treatment. These results proved the good feasibility of using polluted sites as source of mixed consortia for hydrocarbon degradation. However, the diesel degradation efficiencies and rates were very similar, suggesting that the acclimation process produced mixed consortia with very similar characteristics and the origin of the soil samples was not a decisive factor. A simple Monodtype kinetic model was used to simulate the biodegradation process, and accurate results were obtained. As the initial diesel concentration increased, the growth rate and the yield of biomass decreased due to an increase in the energy required to maintain the cultures. The results of this study revealed that the consortia can function at high concentrations of hydrocarbons without any sign of growth inhibition, which is important for the design of bioreactors for wastewater treatment with high concentrations of fuel.

Acknowledgments This research was funded under project CTM2006-03314 by the Spanish Government National Plan for
Research and project PBI08-0206-7303 by the Castilla-La Mancha Regional Government. The financial support (Grant number FSE 2007/2013 PRINCET E08/005) of Alquimia Soluciones Ambientales is gratefully acknowledged.

\section{References}

Al-Saleh E, Drobiova H, Obuekwe C (2009) Predominant culturable crude oil-degrading bacteria in the coast of Kuwait. Int Biodet Biodeg 63:400-406

ASTM D86 (2004) Standard test method for distillation of petroleum products at atmospheric pressure: book of standards. American Society for Testing and Materials, West Conshohocken

Banat IM (1995) Biosurfactants production and possible uses in microbial enhanced oil recovery and oil pollution remediation: a review. Bioresour Technol 51:1-12

Barathi S, Vasudevan N (2001) Utilisation of petroleum hydrocarbons by Pseudomonas fluorescens isolated from a petroleum-contaminated soil. Env Int 26:413-416

Bhandari A, Surampalli RY, Champagne P, Ong SK, Tyagi RD, Lo IMC (2007) Remediation technologies for soils and ground water. American Society of Civil Engineers, Virginia

Boopathy R (2000) Factors limiting bioremediation technologies. Biores Tech 74:63-67

Britton LN (1984) Microbial degradation of aliphatic hydrocarbons. In: Gibson DT (ed) Microbial degradation of organic compounds. Marcel Dekker, Inc., New York, pp 89-129

Chaineau CH, Morel J, Dupont J, Bury E, Oudot J (1999) Comparison of the fuel oil biodegradation potential of hydrocarbon-assimilating microorganism isolated from a temperate agricultural soil. Sci Total Environ 227:237-247

Das N, Chandran P (2011) Microbial degradation of petroleum hydrocarbon contaminants: an overview. Biotechnol Res Int. doi: $10.4061 / 2011 / 941810$

Ghoshal S, Luthy RG (1998) Biodegradation kinetics of naphthalene in nonaqueous phase liquid-water mixed batch systems: comparison of model predictions and experimental results. Biotechnol Bioeng 57:356-366

Iqbal J, Metosh-Dickey C, Portier RJ (2007) Temperature effects on bioremediation of PAHs and PCP contaminated South Louisiana soils: a laboratory mesocosm study. J Soils Sediments 7(3):153158

ISO 9377-2 (2000) Water quality: determination of hydrocarbon oil index. Part 2: method using solvent extraction and gas chromatography. International Organization for Standardization, Geneva

ISO-3675 (1998) Crude petroleum and liquid petroleum productslaboratory determination of density: hydrometer method. International Organization for Standardization, Geneva

Juwarkar AA, Singh SK, Mudhoo A (2010) A comprehensive overview of elements in bioremediation. Rev Environ Sci Biotechnol 9:215-288

Kwapisz E, Wszelaka J, Marchut O, Bielecki S (2008) The effect of nitrate and ammonium ions on kinetics of diesel oil degradation by Gordonia alkanivorans S7. Int Biodet Biodeg 61:214-222

Lafortune I, Juteau P, Déziel E, Pépine F, Beaudet R, Villemur R (2009) Bacterial diversity of a consortium degrading highmolecular-weight polycyclic aromatic hydrocarbons in a two liquid phase biosystem. Microb Ecol 57(3):455-468

Lee JY, Choi YB, Kim HS (1993) Simultaneous biodegradation of toluene and $p$-xylene in a novel bioreactor: experimental results and mathematical analysis. Biotchnol Prog 9:46-53

Macnaughton SJ, Stephen JR, Venosa AD, Davis GA, Chang Y, White DC (1999) Microbial population changes during bioremediation 
of an experimental oil spill. Appl Environ Microbiol 65(8): 3566-3574

Maila MP, Randima P, Surridge K, Dronen K, Cloete TE (2005) Evaluation of microbial diversity of different soil layers at a contaminated diesel site. Int Biodet Biodeg 55:39-44

Margesin R, Schinner F (2001) Biodegradation and bioremediaion of hydrocarbons in extreme environments. Appl Microbiol Biotechnol 56:650-663

Márquez-Rocha FJ, Hernández-Rodriguez V, Lamela MT (2001) Biodegradation of diesel oil in soil by a microbial consortium. Water Air Soil Pollut 128:313-320

Medina-Moreno SA, Huerta-Ochoa S, Gutiérrez-Rojas M (2005) Hydrocarbon biodegradation in oxygen-limited sequential batch reactors by consortium from weathered, oil-contaminated soil. Can J Microbiol 51:231-239

Mukherji S, Weber WJ Jr (1998) Mass transfer effects on microbial uptake of naphthalene from complex NAPLs. Biotechnol Bioeng 60:750-760

Nikakhtari H, Kumar P, Nemati M, Hill GA (2009) Biodegradation of diesel oil in a baffled roller bioreactor. J Chem Technol Biotechnol 84:525-532

Owsianiak M, Chrzanowski L, Szulc A, Staniewski J, Olszanowski A, Olejnik-Schmidt Ak, Heipieper HJ (2009) Biodegradation of diesel/biodiesel blends by consortium of hydrocarbon degraders: effect of the type blend and the addition of biosurfactants. Bioresour Technol 100(3):1497-1500

Paslawski JC, Headley JV, Hill GA, Nemati M (2009) Biodegradation kinetics of trans-4methyl-1-cyclohexane carboxylic acid. Biodegradation 20:125-133

Rahman KSM, Banat IM, Thahira J, Thayumanavan T, Lakshmanaperumalsamy P (2002) Bioremediation of gasoline contaminated soil by a bacterial consortium amended with poultry litter, coir pith and rhamnolipid biosurfactant. Bioresour Technol $81: 25-32$

Ron EZ, Rosenberg E (2001) Natural roles of biosurfactans. Environ Microbiol 3(4):229-236
Sabaté J, Viñas M, Solanas AM (2004) Laboratory-scale bioremediation experiments on hydrocarbon-contaminated soils. Int Biodet Biodeg 54:19-25

Sadouk Z, Hacene H, Tazerouti A (2008) Biosurfactants production from low cost substrate and degradation of diesel oil by a Rhodococcus strain. Oil Gas Sci Technol 63:747-753

Schirmer M, Molson JW, Frind EO, Barker JF (2000) Biodegradation modelling of a dissolved gasoline plume applying independent laboratory and field parameters. J Contam Hydrol 46:339-374

Senez JC (1962) Some considerations on the energetics of bacterial growth. Bacteriol Rev 26:95-107

Torres LG, Rojas N, Bautista G, Iturbe R (2005) Effect of temperature, and surfactant's HLB and dose over the TPHdiesel biodegradation process in aged soils. Process Biochem 40:3296-3302

Ueno A, Ito Y, Yumoto I, Okuyama H (2007) Isolation and characterization of bacteria from soil contaminated with diesel oil and the possible use of these in autochthonous bioaugmentation. World J Microbiol Biotechnol 23:1739-1745

van Uden N (1969) Kinetics of nutrient-limited growth. Annu Rev Microbiol 23:473-485

Vieira PA, Vieira RB, de França FP, Cardoso VL (2007) Biodegradation of effluent contaminated with diesel fuel and gasoline. J Hazard Mater 140:52-59

Whang L-M, Liu P-WG, Ma C-C, Cheng S-S (2008) Application of biosurfactants, rhamnolopid, and surfactin for enhanced biodegradation of diesel-contaminated water and soil. J Hazard Mater 151:155-163

Young C-C, Lin T-C, Yeh M-S, Shen F-T, Chang J-S (2005) Identification and kinetic characteristics of an indigenous dieseldegrading Gordonia alkanivorans strain. World J Microbiol Biotechnol 21:1409-1414

Youssef M, El-Taweel GE, El-Naggar AY, El-Hawary SE, ElMeleigy MA, Ahmed SA (2010) Hydrocarbon degrading bacteria as indicator of petroleum pollution in Ismailia Canal Egypt. World Appl Sci J 8:1226-1233 